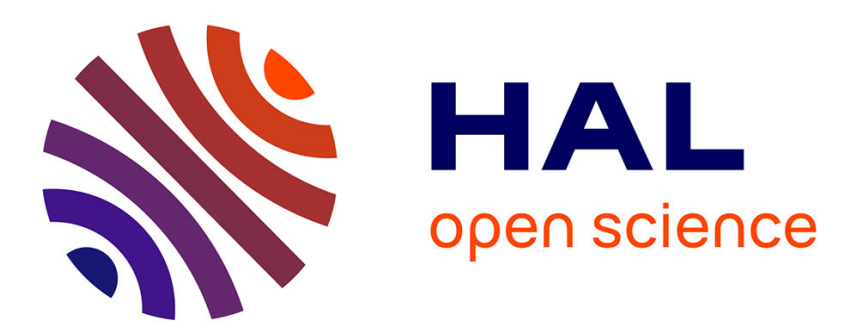

\title{
The State of E-local Participation in Kampala Capital City Authority in Uganda: A Reality or Deception?
}

\author{
Norbert Kersting, Andrew Matsiko
}

\section{To cite this version:}

Norbert Kersting, Andrew Matsiko. The State of E-local Participation in Kampala Capital City Authority in Uganda: A Reality or Deception?. 10th International Conference on Electronic Participation (ePart), Sep 2018, Krems, Austria. pp.76-88, 10.1007/978-3-319-98578-7_7 . hal-01985602

\section{HAL Id: hal-01985602 \\ https://hal.inria.fr/hal-01985602}

Submitted on 18 Jan 2019

HAL is a multi-disciplinary open access archive for the deposit and dissemination of scientific research documents, whether they are published or not. The documents may come from teaching and research institutions in France or abroad, or from public or private research centers.
L'archive ouverte pluridisciplinaire HAL, est destinée au dépôt et à la diffusion de documents scientifiques de niveau recherche, publiés ou non, émanant des établissements d'enseignement et de recherche français ou étrangers, des laboratoires publics ou privés. 


\title{
The state of E-Local participation in Kampala Capital City Authority in Uganda: A reality or deception?
}

\author{
Norbert Kersting ${ }^{1}$ and Andrew Matsiko ${ }^{2}$ \\ ${ }^{1}$ Muenster University, Insistute for Political Science, Muenster, Scharnhorststr. 100, 48151, \\ Muenster, Germany \\ Norbert.kersting@uni-muenster. de \\ ${ }^{2}$ Graduate School of Politics (GRASP), Muenster University, Scharnhorststrasse, 100, 48151, \\ Muenster, Germany \\ matsikoandrew@yahoo.com
}

\begin{abstract}
Because of growing demands and pressures from citizens, political representatives and institutions of governments are increasingly opting for new forms of participation. In other words, a mix of methods is utilised to complement representative participation and city administration. In Uganda, a number of local political representatives: Councilors, Lower level Mayors and Lord Mayor use online participatory instruments; social media platforms: Facebook, WhatsApp, and Twitter to connect with citizens in Kampala capital city authority. However, critical analysis of online participatory instruments for information giving and citizen engagement seems to be lacking. In this regard, a number of possible research questions to critically interrogate are posed. Is the new invited space a reaction to the invited bottom up participation? What forms of digital participatory spaces does Kampala Capital City Authority use to disclose information on its operations? What is the mix of offline- and online channels (blended participation) do local political representatives use to connect with electorates? Is this more for planning or for monitoring purposes. To answer these questions, both quantitative data (survey) and qualitative interview is used.
\end{abstract}

Keywords: Local E-participation, Online and offline instruments, Local representation and electorate engagement.

\section{Introduction}

The disconnection of local political representatives from electorates in the processes of making of social, economic and political decisions is increasingly growing in representative democracies around the globe [1]. In fact, Younger democracies are often regarded as having only degenerated into purely electoral democracies. But the older democracies also show symptoms of a participatory and legitimisation crisis of the political system. For instance, globally, electoral representative democracies are highly criticised. They characterise high rates of voter apathy, cynicism and disinterest in conventional political [2].

In addition, political parties in representative democracies lack political debates in which, for instance political parties are often seen as empty railway stations or abandoned pizzas, in which 
political debates are lacking (see for this metaphors used by Touraine) [3, 4]. Here a trend towards right wing populist party is obvious [5].

However, as a result of increasing deterioration of conventional participation in representative democracies and deficiencies of good governance [6]. In recent decades, most of the representative governments were confronted with strong protest and demonstrations and bottom up participation in the invited spaces [7, 8, 9]. Political systems reacted and implemented new invited spaces in form of referendums, round tables or forums for the purposes of engaging citizens in the making of social, economic and political decisions. However, some of these new experiments were found being dominated by political parties and formal institutions. In this case, the people were still not satisfied, and found their own channels to express their interest using invented spaces as an answer to this hierarchically dominated intervention. New forms of protest and participation were developed as a kind of public counterweight to existing structures. They were used to challenge existing power structures and dominance by the old ruling elites [7].

In Uganda particularly in urban local governments, local political representatives and electorates as well as experts in administration are using online participatory instruments to engage each other in social, economic and political decision-making. A number of online participatory instruments such as twitter, Face-book, and Instagram etc. are already in place for which the local electorates engage political leaders and technical wings in public institutions. This paper therefore presents the state of E-local participation in Kampala Capital City Authority (KCCA) in Uganda. The paper focuses on interrogating questions: what are the forms of digital and analogue spaces KCCA uses to disclose information and to discuss? What are online channels that local political representatives use to engage their electorates? How important are these online participatory instruments? Is it more deliberative or demonstrative participation? Is the new invited space a reaction towards protest (invented space) or is it provoking new forms of protest?

\section{Participatory Rhombus in Uganda}

Participation is an act of citizen involvement of citizens the aim to influence political decisionmaking $[10,11]$. Participatory Rhombus localises this engagement in four different spheres of politics. All four spheres exist in the digital online and offline worlds. These include; participation in representative democracy, participation in direct democracy, deliberative participation and demonstrative participation. Below, the participatory rhombus explains these and their location in the "invented space" as bottom up participation and "invited" spaces as a platform built by government from above'. In the dominating representative sphere of politics, participation focuses on the elected members of Parliament and the Executive. Here elections and voting are important, as well as direct contacts with politician's political party membership etc. In multiethnic Uganda after independence, the multiparty political system was facing conflicts. After years of civil war and dictatorship, the new president Museveni introduced a No-Party System with a kind of inner-party democratic competition and a strong president. This concept lost its appeal with the winds of change in 1989.

Nevertheless, with the dominating president, Uganda still seems to be a de facto one party system and a liberal electoral democracy. In the dominating representative sphere of politics, participation focuses on the elected members of Parliament and the Executive. Here elections and voting are important, as well as direct contacts with politician's political party membership 
etc. In multiethnic Uganda after independence, the multiparty political system was facing conflicts. After years of civil war and dictatorship, the new president Museveni introduced a NoParty System with a kind of inner-party democratic competition and a strong president. This concept lost its appeal with the winds of change in 1989. Nevertheless, with the dominating president, Uganda still seems to be a de facto one party system and a liberal electoral democracy. At the local level, elections are partially non-existent, for instance, lower local councils: village, parish and women council representatives, but the representatives often act in a kind of competitive, neo-patrimonial clientelistic system. The direct contact between the councilors, administration and the citizen is crucial and it was extended in recent years by new online channels. Most participatory instruments focus on these two groups. Beside important strategies for information (web-portals, electronic newsletters), new online instruments become more an element of communication between administration as well as politicians and citizen. Here the mobile telephone, SMS is an important channel for top down and bottom up information and communication.

Direct democratic action, which means the vote on thematic issues, including a vote in a numeric democracy only existed at the national level. Here two important referendums were important. One end up in favour of the no party system and one - some years later-in favour of the new multiparty system. Both showed the strong influence of the ruling party and the president in referendums [12]. Sub-national off-line direct democratic participation, such as local referendums and initiatives do not exist. Online instrument in this regard include forms of participatory budgeting, where it can be voted for suggestions. In general, citizen can react in posting different messages towards administration and politicians. Here this was enabled by instruments incorporating an online comments-function for citizen, as well as by social media forums using Facebook or Twitter. Complaint chat rooms as well as e-petitions do not exist, but social media and messenger are used instead.

\section{Participatory Rhombus in Uganda - Online- and Offline-Participation}

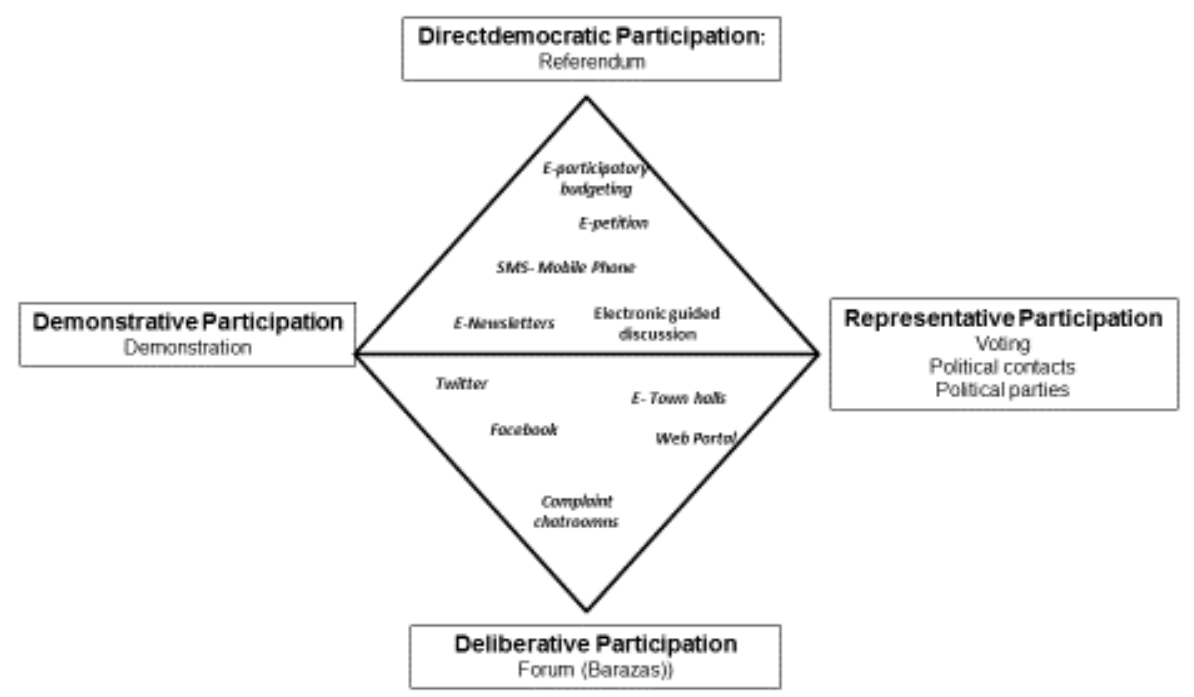


Fig. 1: Participatory Rhombus in Uganda- Online and Offline Participation [7]

At the national as well as at the local level government of Uganda included the different deliberative platforms called Baraza which allowed information but also discussion between policymakers, development partners and citizen. The quality of deliberation is often dependent on the willingness of the administration and politicians allowing open and free discussions. In the online deliberation the conduction of narrated unguided discussion forums allow a broader deliberation. But regular electronic town hall meetings do not exist. Because of this low deliberative quality, most of the direct democratic and the deliberative participation were not a reflexive deliberation based on good arguments, but more an expressive demonstrative participation. So this engagement can be ascribed to the fourth sphere of demonstrative participation.

Beside this form of expressive participation, in Uganda demonstration on the streets often are organized by special interest groups such as doctors and protesting in favour of higher salaries and better working conditions etc. and environmentalists who often demonstrate against government intentions of selling off of protected natural forests and watersheds. Similarly, the unemployed youth groups have often demonstrated at the parliament against corruptions and lack of welfare and employment as well as "walk to work" street protests by the opposition and citizens against inflation and skyrocketing cost of living in Uganda in between 2010 and 2012.

\section{Politicians and Administrations perspective: Empirical findings}

This paper uses data generated from a questionnaire survey which was carried out in Kampala city from January to June in 2017 on local political representatives (Councilors) in local urban governments. A total number of 157 local representatives were given a questionnaire to respond to questions on online participation in Kampala city authority. They were considered because of their fair knowledge on use of online participatory instruments. Experts in the administration were contacted to establish the online participatory instruments and administrative innovations used in place. Interviews were conducted within the directorate of communication and research. The information from interviews reveals that there are a number of online instruments and administrative innovations: complaint management and monitoring tools, participatory budgeting, mobile short text messages (SMS), Municipal/City Facebook/WhatsApp, web-portals and electronic newsletters etc. They are used for inclusion of different stakeholders in city projects, for instance, "visit Kampala", "Kampala for climate change", "urban faming", and "urban infrastructure", especially for monitoring and management of complaints about infrastructure and service delivery in the city etc.

The information from online instruments is interlinked to the relevant directorates for utilisation, management and planning, which in terms of policy implications facilitates the formulation of sustainable, effective and efficient policies as well as planning and monitoring operations of the city authority. The generated data from a questionnaire survey was analysed using SPSS package and Microsoft-excel. Thus, below is the presentation of findings in a graphic form. They show the importance of online participatory instruments, and online instruments in which local political representatives, citizens and administrators participate in or they use to participate in political and administrative operations of city (see, figure. $2 \& 3$ ), and the effects of online enabled instruments on quality and quantity of information in local politics and administration (see, figure. 4). 
Participatory budgeting

The use of mobile telephone SMS

Municipal social media forum (City facebook)

Enabling citizens to post comments

Conduction of one or more nonnarratted or guided...

Web portals of the council

The facilitation or operation of complaint chat rooms

Electronic news letters to the subscribers

Permittance or facilitation of electronic petitions

Conduction of electronic town halls

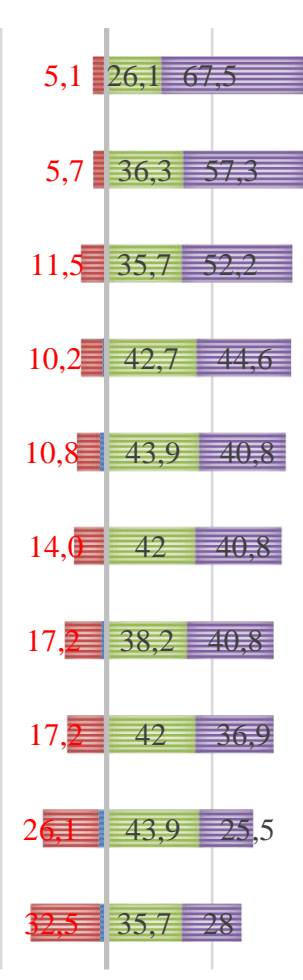

$\begin{array}{llll}50 & 0 & 50 & 100\end{array}$
트 Very bad

E Not important

틀 Important

E Very important

Fig.2. Importance of online participatory instruments used by Kampala Capital City Authority (KCCA) Source: Own research 2017

How important are online participatory instruments? The findings of the study indicate that a highest proportion of respondents (42\%) reveal that electronic newsletters are important online instruments, while $(36.9 \%)$ reveal them as very important. On the other hand, respondents (17.2\%) find newsletters not important and only a small portion (1.3\%) indicate that electronic newsletters are very bad for participation. In addition, slightly above every four in ten $(42.0 \%)$ of responses reveal that web portals are important, while almost a similar figure (40.8\%) show that web portals are very important, and only $(14 \%)$ note that they are not important.

Furthermore, slightly above every five in ten $(52.2 \%)$ of respondents reveal that the use of Municipal/city Facebook or WhatsApp is very important for participation in the city, while $(35.7 \%)$ further reveal that Municipal/city Facebook/WhatsApp is important and only (11.5\%) of responses find Facebook/WhatsApp not important. With regard to mobile telephone (SMS), a smaller portion of respondents $(0.6 \%)$ reveal that they (SMS) are very bad, and only $(5.7 \%)$ of responses find it (SMS) not important. On the other hand, portion of slightly above every three in ten $(36.3 \%)$ of respondents show that the use of mobile telephone (SMS) is important, and a significant majority of responses $(57.3 \%$ ) reveal that the uses of mobile telephone (SMS) is very important in politics and administration of the city authority.

The posting of comments is very bad as revealed by a small number of respondents $(1.9 \%)$, and about $(10.2 \%)$ of responses find it not important. While on the other hand, respondents 
slightly above every four in ten $(42.7 \%)$ indicate that enabling of citizens to post comments is important, and majority respondents $(44.6 \%)$ indicate that it is very important.

For the conduction of electronic town halls, respondents $(3.2 \%)$ reveal that it is very bad, while about $(32.5 \%)$ indicate that they are not important. On the other hand, the study findings (35.7\%) and approximately (28\%) of respondents reveal electronic town hall is important and very important respectively. In addition, a slightly small numbers of responses $(3.8 \%)$ view that electronic petitions are very bad, and about $(26.1 \%)$ reveal them as not important. On the other hand, the majority $(43.9 \%)$ and $(25.5 \%)$ of responses indicate that they are important and very important respectively.

Furthermore, study findings $(1.3 \%)$ indicate that participatory budgeting is very bad, while about $(5.1 \%)$ responses view it not important. While on the other hand, the responses $(26.1 \%)$ reveal participatory budgeting is important, and majority responses of slightly above every six in ten $(67.5 \%)$ find it very important.

Complaint chat rooms are very bad with $(2.5 \%)$ of responses, and similarly, responses $(17.2 \%)$ find it not important. While on other hand, about $(38.2 \%)$ of responses reveal that it is important, and majority with slightly above every four in ten $(40.8 \%)$ further indicate that the complaint chat rooms are very important. However, it is further worthy noting that the use of complaint chat rooms is currently not available or implemented. The responses $(3.2 \%)$ indicate that one or non-narrated guided discussion is very bad, while still $(10.8 \%)$ is not important. On the other hand, about $(43.9 \%)$ of responses reveal that it is important, while majority $(40.8 \%)$ view it as very important.

The use of mobile telephone SMS

Municipal social media forum (city...

Participatory budgeting

One or more non-narratted or guided discussions...

Web portals of the council

Electronic news letters to the subscribers

Enabling citizens to post comments

Electronic town halls

Electronic petitions

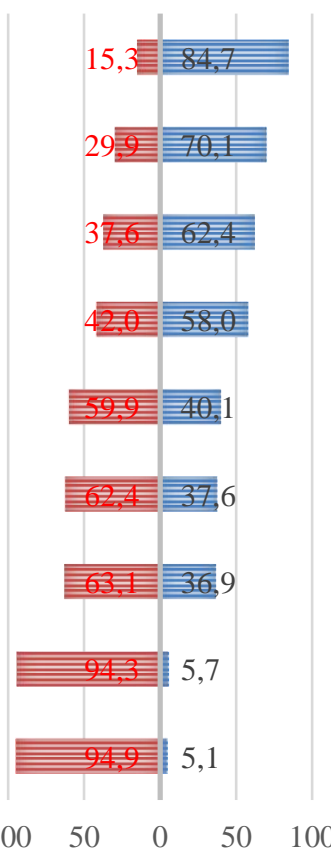

E Participated/have used

EN Not yet used

$\begin{array}{llllll}150 & 100 & 50 & 0 & 50 & 100\end{array}$

Fig. 3. Participatory online instruments used by councilors in the city. Source: Own research 2017 
To whether respondents have participated or which online instruments they have used to participate, the respondents $(37.6 \%)$ reveal that they have participated in local politics using electronic newsletters. Electronic newsletters facilitate the sharing and exchange of information to subscribers' emails between technocrats and local representatives. However, majority of the local representatives slightly above every six in ten $(62.4 \%)$ have not yet used electronic newsletter to disseminate information, which implies that they have not yet subscribed to receive newsletters from either political or administrative wings of the authority. Electronic newsletters summarise quarterly and annual information, which is at times received by the local representatives on standing committees: the local public accounts committees, infrastructure and environment and public health committees etc.

In addition, responses $(40.1 \%)$ shows that they have participated in politics or have used web-portals, while the highest number (59.9\%) reveal that they have not yet participated using web portals to access information on operations of the council and participated in council politics. More still, the majority of respondents slightly above every seven in ten $(70.1 \%)$ participated or used municipal/city Facebook or WhatsApp to participate and engage citizens, and only a smallest number (29.9\%) have not yet participated or used municipal/city Face-book/WhatsApp in the engagement of electorates in social, political and economic decision making. This instrument especially Facebook is highly used because of availability of simple digital devices unlike others that necessitate high advanced gadgets.

More so, the use of mobile telephone (SMS) is high with (84\%) of respondents, while a few respondents (15.3\%) have not yet used mobile telephone (SMS) to participate in urban local governments. The highest use of mobile telephone (SMS) is highly attributed by the nature of the low speed of internet and user friendly of (SMS) on non-complicated high tech digital devices to reach a mass of local citizens. Furthermore, about (36.9\%) of respondents: political and administrative wing have participated in enabling of citizens to post comments, while majority of slightly above every six in ten $(63.1 \%)$ have not yet used the posting of comments to connect with electorates.

On the other hand, only (5.7\%) of respondents use or participate in electronic town halls, while the highest number of respondents $(94.3 \%)$ have not yet used or participated in urban local government. More still, about $(5.1 \%)$ of the respondents participate or use electronic petitions to engage in council politics, while the highest numbers $(94.9 \%)$ have not yet participated or used electronic petitions.

With regard to participatory budgeting, about above every six in ten $(62.4 \%)$ of respondents participate and have used online budgeting. Here citizens contact representatives on their online platforms where they suggest their budget priorities to representative. While slightly above every three in ten respondents (37.6\%) have not yet used it to participate.

In addition, majority of the respondents $(91.1 \%)$ have not yet participated or used complaint chat rooms to engage in politics and connect with the citizens. The conduction of one or more none guided discussions are also gaining use, for instance, about $(58.0 \%)$ of respondents participate using it, while (42\%) have not yet used it. 
The quantity of information to

local officials for better decisionmaking

Direct participation of citizens in politics

The quantity of participation of citizens

The quality of information to local officials for better decisionmaking

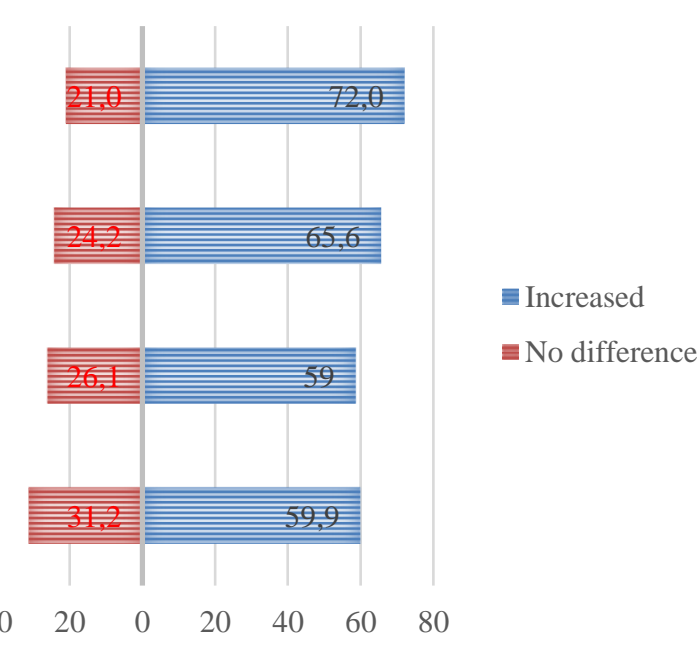

Fig. 4. The effects of online enabled participatory instruments on quality and quantity of citizen participation. Source: Own research 2017

The online enabled participatory instruments have had different effects on quality and quantity information and participation in the city authority. For instance, the majority of the respondents (72\%) reveal that online participatory instruments increased quantity of information for better local decision-making, while, respondents $(21 \%)$ indicate that there is a no difference. Furthermore, slightly above every five in ten of respondents (59.9\%) indicate that there is an increase of quality of information to experts in administration for better decision-making, while respondents $(31.2 \%)$ refuted. In terms of quantity of participation, majority of respondents (58.6\%) reveal that online participatory instruments increased the quantity of citizen participation in local politics, while a small number of respondents $(26.1 \%)$ refuted the statement as well.

Lastly, with regard to the effects of online participation on direct participation, respondents (24.2\%) indicate that online participatory instruments had no influence on direct citizen participation in politics, while the majority of respondents $(65.6 \%)$ indicate that online participatory instruments increased the quantity of direct citizen participation in politics.

\section{Conclusions}

In fact, online participation seems to lead more to a blended democracy and not to a virtual political life in the internet. Blended democracy describes the interaction between online and offline participation and online and electronic democracy. Furthermore, E-democracy produces an invented space and a broad range of third space [18], which included protest against government and which lead to a higher responsiveness. In Uganda, for instance, local urban governments, a number of online instruments for political and administrative engagement are so far slowly emerging to connect political representatives, administrators and citizens in the administration and political decision making of the city in Kampala. The instruments in use include; Municipal social media forums or city face-book, electronic newsletter, electronic petitions, operation of electronic town halls, WhatsApp groups of local representatives, use of mobile telephone (SMS), online participatory budgeting, twitter, Instagram among others (e.g. see, figure $2 \& 3$ above). 
However, the local electronic participation (instruments) are implemented by both the city authority (political and administrative wings) and while others are opened implemented by the individual local political representatives. For instance, the political representatives such as the lord mayors (political head-City hall) and lower urban mayors as well as local councilors manage their individual social media platforms for political engagement and connection of the electorates. Similarly, local political representatives use online platforms instituted by the urban government for internal online participation with local political leaders themselves in regard to political operation and decision-making. However, some of the online participatory instruments are not yet implemented, for instance, electronic town halls, operation of complaint chat rooms and electronic petitions. A development towards a regulary implemented electronic town hall meetings would enhance this instrument.

Nonetheless, online participation is seriously used by local political representatives to participate in politics of the council as well as engaging with the citizens. From the study results, it is in fact indicated that a number of social media forums are more used than others, for instance, political representatives use municipal/city Facebook, mobile telephone (SMS), web portals, and electronic newsletters among others. On the other hand, the technical administrations use also almost the same means for engagement of citizens in issues such as service delivery and provision enquiries, tax-bargain and payment, information giving and complaint management. For example, the administrative wing uses social media, Twitter, Instagram, mobile telephone (SMS) and city WhatsApp groups for complaint management and service provision improvement in the city.

In general, it seems quite obvious that the new digital media are predominantly used in a kind of top down instrument to inform citizen about administration as well as the politicians. The new instruments for what kind of bilateral participation and real reflexes communication, are less developed. Here the focus more on information towards the administration and politicians about problems and complaints. This monitoring function of the online participation predominates. Next steps should include new forms of community planning and citizen source participation in the decision-making processes for new policies.

\section{References}

1. Lijphart, A.: Democracy in the 21th century. Can we be optimistic? In: Kersting, N., Cronqvist, L. (eds.) Democratisation and Political Culture in Comparative Perspective, VSSpringer, Wiesbaden (2005)

2. Norris, P.: Democratic Dreferendeficit. Cambridge University Press, New York (2011).

3. Kersting, N., Janice, C., Andrew N., Dele, O., Hellmut, W.: Local governance reform in a global perspective. VS, Wiesbaden (2009)

4. Touraine, A.: The Post Industrial Society. Random House, New York (1971).

5. Mudde, C., Rovira, K, C.: Exclusionary vs. Inclusionary Populism: Comparing Contemporary Europe and Latin America. In: Government and Opposition 48(2), 147-174 (2013).

6. Hague, B, N., \& Loader, B, D. (eds.) Digital Democracy: Discourse and Decision making in the information Age. Routledge, London (1999)

7. Kersting, N.: Online Participation: from "invited" to "invented" spaces. International Journal of Electronic Governance 6(4), 270-280 (2013).

8. Barber, B.: Strong Democracy. Berkeley Press, Berkeley (1984).

9. Budge, I.: The New Challenge of Direct Democracy. Polity Press, Oxford (1996).

10. Barnes, S., Kaase, M.: Political Action. Sage, Beverly Hills (1979)

11. Berg-Schlosser, D., Kersting, N.: Poverty and democracy: Self-help and political participation in third world cities. Zedbooks Ltd, London (2003)

12. Qvotrup, M.: Referendums around the World. Palgrave, London (2017) 
13. Siegle, J.: ICT and Accountability in Areas of limited Statehood. In: Livingston, S., Drop Walter, G. (eds.) Bits and Atoms: Information and Communication Technology in Areas of Limited Statehood, pp. 61-75. Oxford University Press, New York (2014).

14. Srinivasan, S.: FrontlineSMS, Mobile-for-Development, and the "Long Tail" of governance. In: Livingston, S., Drop-Walter, G. (eds.) Bits and Atoms: Information and Communication Technology in Areas of Limited Statehood, pp. 79-97. Oxford University Press, New York (2014).

15. Livingston, S., Drop-Walter, G. (eds.) Bits and Atoms: Information and Communication Technology in Areas of Limited Statehood, pp. 79-97. Oxford University Press, New York (2014).

16. Kersting, N.: Local Political Participation in Europe: Elections and Referendums. HKJUCCPA 15(2), 319-334 (2015).

17. Kersting, N.: Participatory turn? Comparing citizen and politicians perspectives on Online and Offline local political participation. In: Lex localis - Journal of Local Self-Government 14(2), 225-249 (2016)

18. Fung, A. \& Wright, E.O. (eds.) Deepening Democracy. Verso, London (2003).

\section{Appendix: Questionnaire}

Dear respondent: I am from Münster University, Germany. I am carrying out academic research on "Local Taxes and ICTs in Uganda: Good Governance by Participation and Transparency?" I request for your inputs towards my research. Your views, opinions, comments and expressions are treated with utmost confidentiality. However, your participation is only for academic purposes and voluntary. You are at liberty to contribute, refuse or withdraw at any time.

A) Online participatory instruments by the city council.

\begin{tabular}{|c|c|c|c|c|c|c|c|}
\hline \multicolumn{6}{|c|}{ What is important in local politics? } & \multicolumn{2}{|c|}{$\begin{array}{l}\text { What have you } \\
\text { personally used or } \\
\text { where did you par- } \\
\text { ticipate? }\end{array}$} \\
\hline & $\begin{array}{l}\text { Very im- } \\
\text { portant }\end{array}$ & $\begin{array}{l}\text { im- } \\
\text { portant }\end{array}$ & $\begin{array}{l}\text { Not im- } \\
\text { portant }\end{array}$ & $\begin{array}{l}\text { Very } \\
\text { bad }\end{array}$ & D.K & $\begin{array}{l}\text { Have used. } \\
\text { Have parti- } \\
\text { cipated }\end{array}$ & $\begin{array}{l}\text { Not } \\
\text { yet }\end{array}$ \\
\hline $\begin{array}{l}\text { Conduction of } \\
\text { one or more } \\
\text { non-narrated or } \\
\text { guided discus- } \\
\text { sion forums } \\
\text { about important } \\
\text { local issues }\end{array}$ & $\square$ & $\square$ & $\square$ & $\square$ & $\square$ & $\square$ & $\square$ \\
\hline $\begin{array}{l}\text { Facilitation } \\
\text { operation } \\
\text { complaint of } \\
\text { rooms }\end{array}$ & $\square$ & $\square$ & $\square$ & $\square$ & $\square$ & $\square$ & $\square$ \\
\hline
\end{tabular}




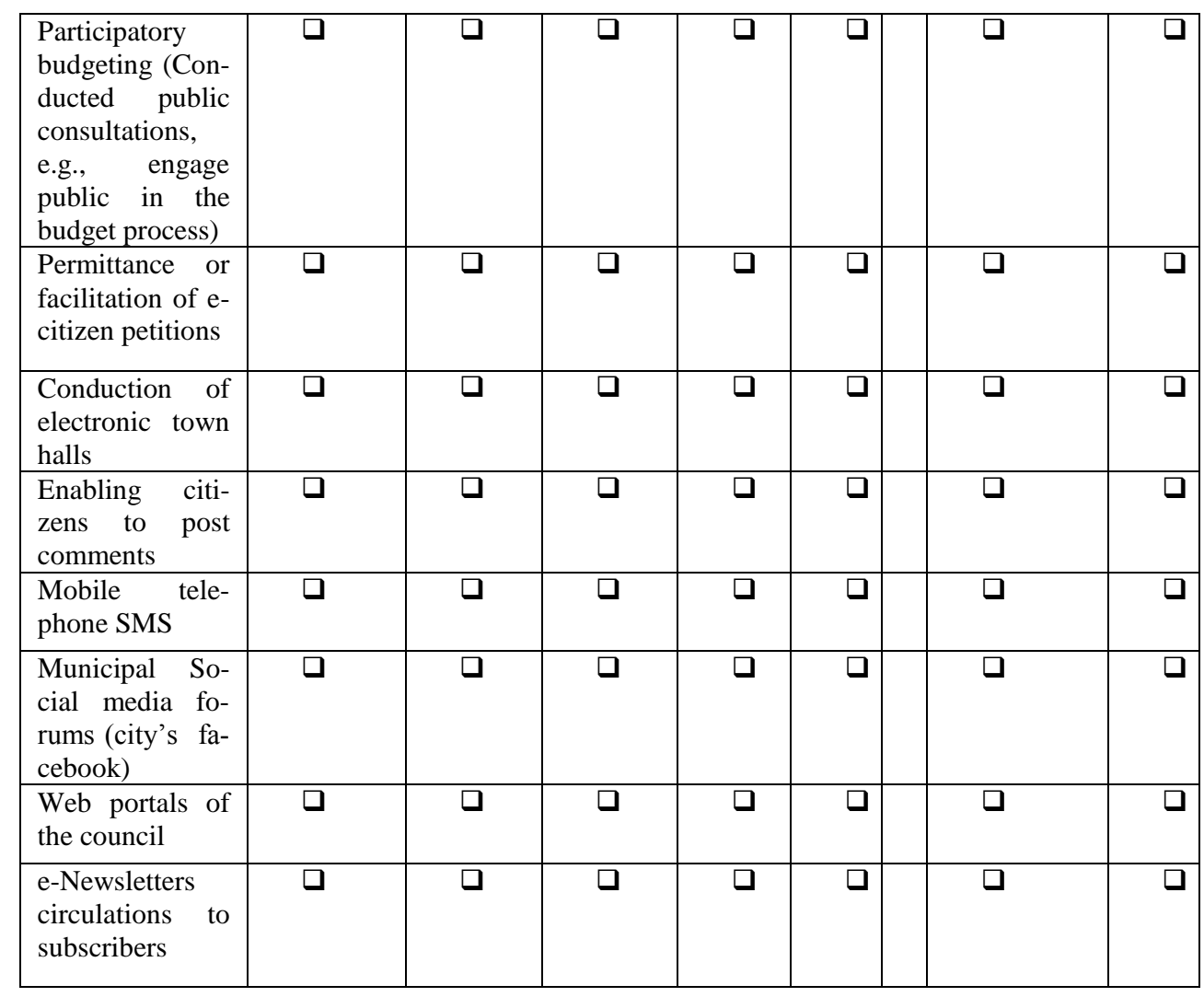

B) ICT ENABLED QUALITY OF PARTICIPATION

Thinking about the results of electronic participation, how has local government experienced the following benefits of electronic participation?

\begin{tabular}{|l|c|c|c|c|}
\hline & Increased & No difference & Decreased & Don't know \\
\hline $\begin{array}{l}\text { Quantity of information to local offi- } \\
\text { cials for better decision-making }\end{array}$ & $\square$ & $\square$ & $\square$ & $\square$ \\
\hline $\begin{array}{l}\text { Quality of information to local offi- } \\
\text { cials for better decision-making }\end{array}$ & $\square$ & $\square$ & $\square$ & $\square$ \\
\hline Quantity of citizen participation & $\square$ & $\square$ & $\square$ & $\square$ \\
\hline Direct citizen participation in politics & $\square$ & $\square$ & $\square$ & $\square$ \\
\hline Other specify & $\square$ & $\square$ & $\square$ & $\square$ \\
\hline
\end{tabular}


C) Socio-Demographic Information

\begin{tabular}{|c|}
\hline What is your sex? \\
\hline $\begin{array}{l}\text { What is your age category? } \\
\begin{array}{l}\text { a) } 18-29 \\
\end{array}\end{array}$ \\
\hline $\begin{array}{l}\text { What is your Marital Status? a) Married } \square \\
\begin{array}{llll}\text { d) Separated } \square & \text { e) Divorced yet married } \square & \text { c) Widowed } \square\end{array}\end{array}$ \\
\hline $\begin{array}{l}\text { What is your highest level of education? a) No education } \square \text { b) Primary } \square \text { c) Secondary } \\
\text { d) Tertiary } \square \text { e) University } \square\end{array}$ \\
\hline $\begin{array}{l}\text { What is your Employment Status? a) Not employed } \square \text { b) Self-employed } \square \text { c) public service } \\
\text { d) Private sector employee } \\
\begin{array}{ll}\text { d) }\end{array}\end{array}$ \\
\hline $\begin{array}{l}\text { What is your monthly income? } \\
\text { What is your religion? a) Roman catholic } \square \text { b) Protestant } \square \text { c) Pentacostal } \square \text { d) Muslim e) Non } \\
\begin{array}{ll}\text { c) What is your ethinicity? }\end{array}\end{array}$ \\
\hline
\end{tabular}

(This is only part of the sections of the whole instrument) 